\title{
RECONNAISSANCE SEDIMENTOLOGY OF SELECTED TERTIARY EXPOSURES IN THE UPLAND REGION BORDERING THE YUKON FLATS BASIN, EAST-CENTRAL ALASKA
}

David L. LePain and Richard G. Stanley

Preliminary Interpretive Report 2016-6
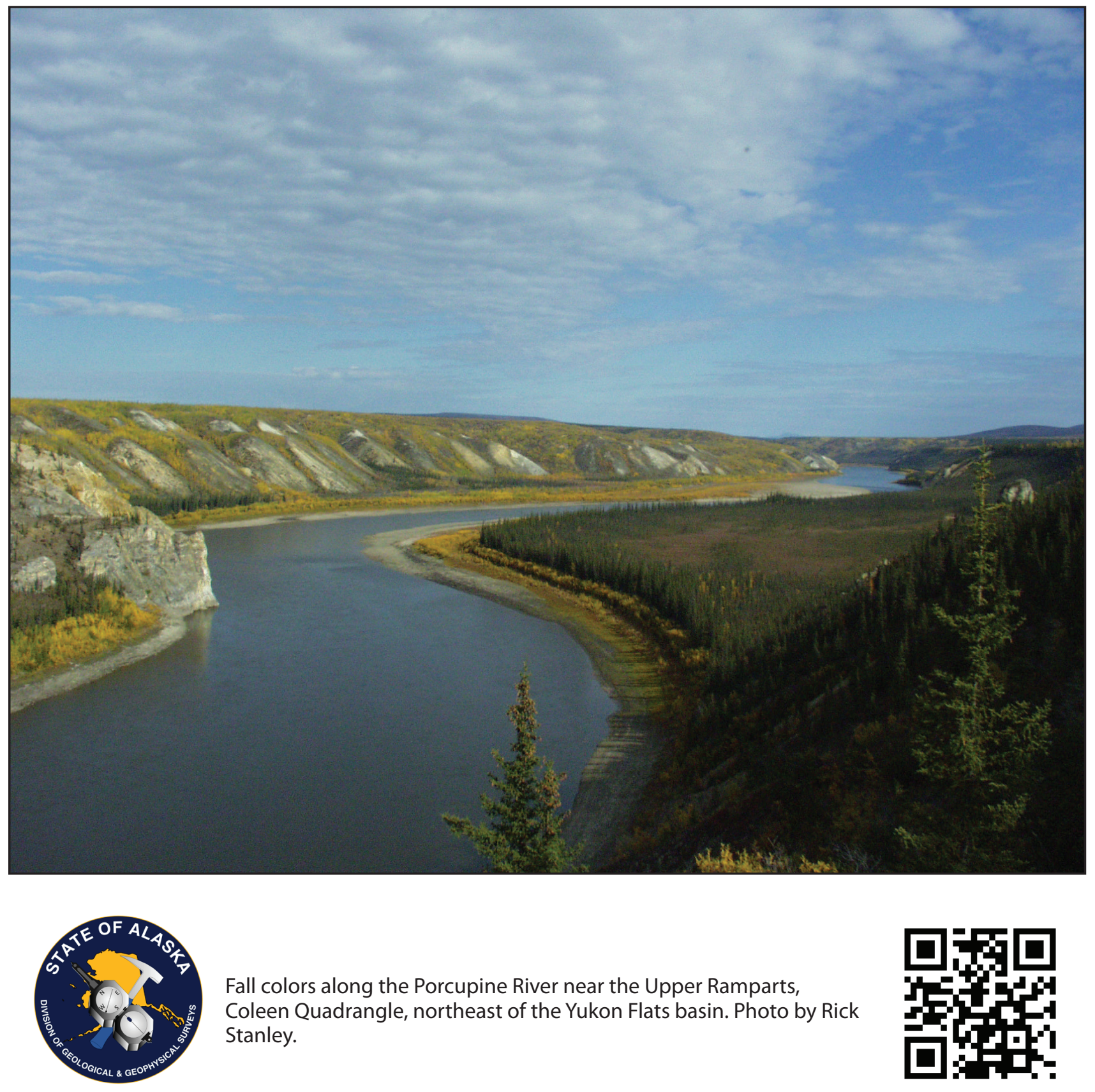

Fall colors along the Porcupine River near the Upper Ramparts,

Coleen Quadrangle, northeast of the Yukon Flats basin. Photo by Rick Stanley.

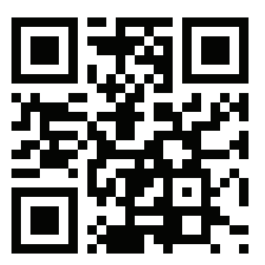





\section{RECONNAISSANCE SEDIMENTOLOGY OF SELECTED TERTIARY EXPOSURES IN THE UPLAND REGION BORDERING THE YUKON FLATS BASIN, EAST-CENTRAL ALASKA}

David L. LePain and Richard G. Stanley

Preliminary Interpretive Report 2016-6

\section{Alaska Department of Natural Resources \\ Division of Geological \& Geophysical Surveys}

3354 College Road

Fairbanks, Alaska 99709-3707

(907) 451-5010 | dggspubs@alaska.gov

website: dggs.alaska.gov 
STATE OF ALASKA

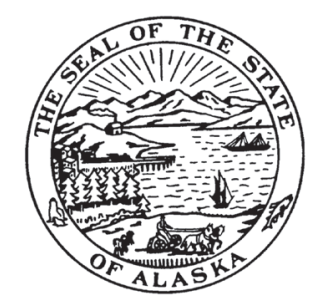

Bill Walker, Governor

DEPARTMENT OF NATURAL RESOURCES

Andrew T. Mack, Commissioner

DIVISION OF GEOLOGICAL \& GEOPHYSICAL SURVEYS

Steve Masterman, State Geologist and Director

Publications produced by the Division of Geological \& Geophysical Surveys (DGGS) are available for download from the DGGS website (dggs.alaska.gov). Publications on hard-copy or digital media can be examined or purchased in the Fairbanks office:

\section{Alaska Division of Geological \& Geophysical Surveys}

3354 College Rd., Fairbanks, Alaska 99709-3707

Phone: (907) 451-5010 Fax (907) 451-5050

dggspubs@alaska.gov|dggs.alaska.gov

DGGS publications are also available at:

Alaska State Library, Historical

Collections \& Talking Book Center

395 Whittier Street

Juneau, Alaska 99811
Alaska Resource Library and Information Services 3150 C Street, Suite 100 Anchorage, Alaska 99503-3982 


\section{CONTENTS}

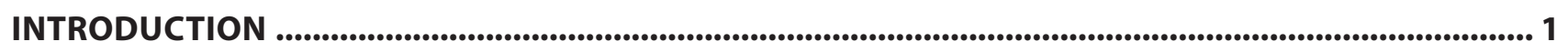

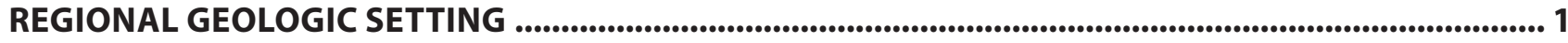

DESCRIPTION OF SELECTED OUTCROPS VISITED DURING 2002 FIELD SEASON ................................... 2

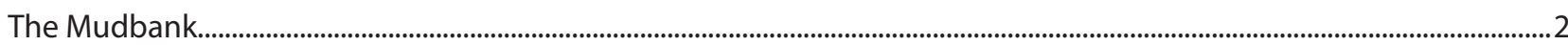

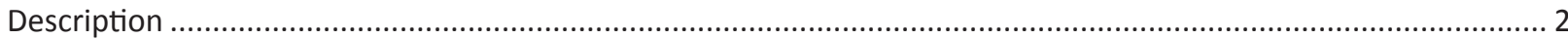

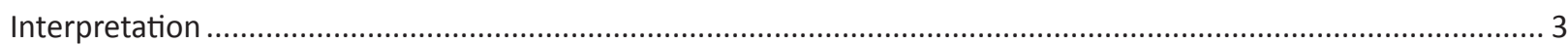

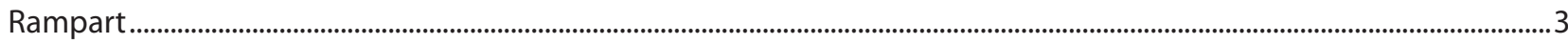

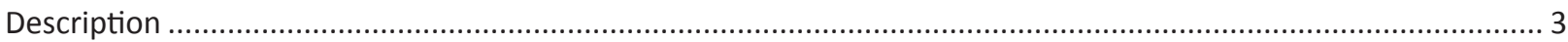

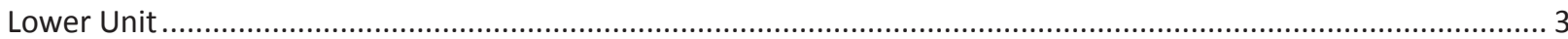

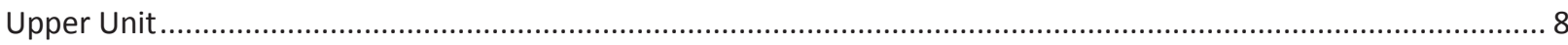

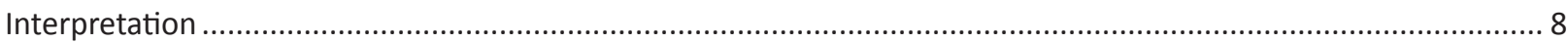

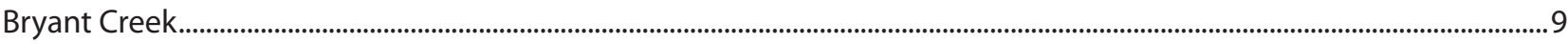

Description

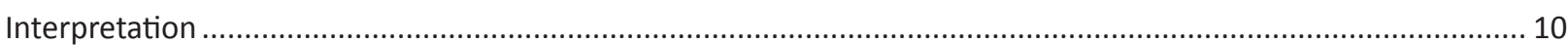

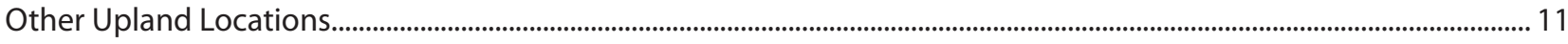

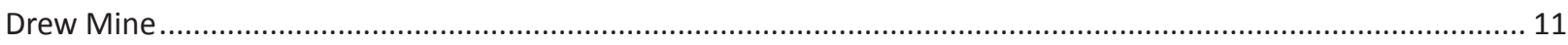

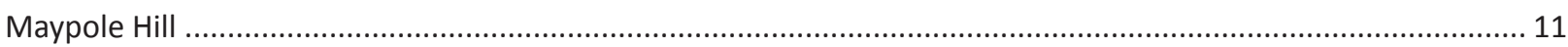

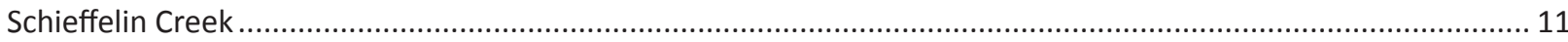

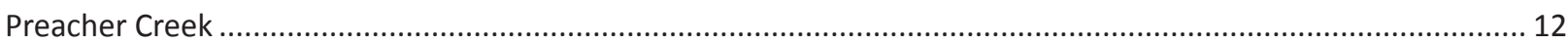

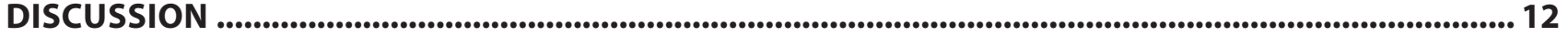

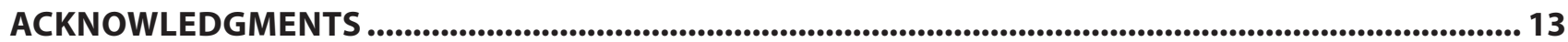

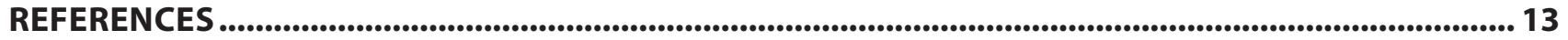

\section{FIGURES}

1. Generalized geologic map of the Yukon Flats basin and surrounding uplands .................................................................4

2 Photomosaic and selected facies exposed at The Mudbank, Hodzana River, Beaver C-3 Quadrangle..........................5

3. Reconnaissance measured stratigraphic sections from The Mudbank, Hodzana River......................................................6

4. Tertiary nonmarine strata exposed on the east bank of the Yukon River, between Julia Creek and Argo Gulch, upstream from Rampart, in the Tanana C-1 Quadrangle................................................................................................7

5. Tertiary nonmarine strata exposed along the northwest side of Bryant Creek, in the Eagle D-1 Quadrangle...........9

6. Reconnaissance measured section through lacustrine and fluvial strata exposed along Bryant Creek.................... 10 



\title{
RECONNAISSANCE SEDIMENTOLOGY OF SELECTED TERTIARY EXPOSURES IN THE UPLAND REGION BORDERING THE YUKON FLATS BASIN, EAST-CENTRAL ALASKA
}

\author{
David L. LePain ${ }^{1}$ and Richard G. Stanley ${ }^{2}$
}

\section{INTRODUCTION}

This report summarizes reconnaissance sedimentologic and stratigraphic observations made during six days of helicopter-supported fieldwork in 2002 on Tertiary sedimentary rocks exposed in the upland region around the flanks of the Yukon Flats basin in east-central Alaska (fig. 1). This project was a cooperative effort between the Alaska Division of Geological \& Geophysical Surveys (DGGS) and the U.S. Geological Survey (USGS) to investigate the geology of the basin in preparation for an assessment of the undiscovered, technically recoverable hydrocarbon resources (Stanley and others, 2004).

Field observations and interpretations summarized in this report are reconnaissance level. At most, no more than a few hours were spent on the ground at any location. Measured sections included in this report are sketch sections and thicknesses shown are approximate. Relatively detailed observations were made by the authors at only three locations, including The Mudbank (Hodzana River), Rampart (east bank of the Yukon River), and Bryant Creek (along the Tintina fault near the Canada border). These three locations are described first in relative detail, then followed by general descriptions of other locations.

Additional information on the geology of the Yukon Flats basin is available from the USGS and DGGS. A compilation bedrock geologic map was published by Till and others (2006). Exxon Company, U.S.A., drilled a series of shallow coreholes in the uplands bordering the basin in the mid-1980s to obtain rock samples for evaluation of age, petroleum reservoir potential, and petroleum source rock potential. LePain and Montayne (2016) described more than 700 core samples collected from the drilled materials. Reifenstuhl (2006) used these descriptions to identify samples for petrographic analysis and porosity and permeability measurements. He also included samples collected from outcrops visited during the 2002 fieldwork.

\section{REGIONAL GEOLOGIC SETTING}

The Yukon Flats basin is a 70(?)-million-year-old extensional basin associated with strike-slip movement along the Tintina fault system (Till and others, 2005, 2007; Rowan and Stanley, 2008). The basin is in east-central Alaska, between the Dalton Highway and the Canada border (fig. 1). Accreted terranes consisting of structurally complex, variably metamorphosed sedimentary and igneous rocks border the Yukon Flats basin on the south, west, and north sides (Silberling and others, 1994; Till and others, 2006). Rocks more favorable to oil and gas border the basin to the east in the Kandik basin, where they have been structurally modified to form a fold-and-thrust belt (Dover, 1992; Van Kooten and others, 1997). The north side of the basin is bounded by oceanic rocks, including pillow basalts and bedded cherts, of the Angayucham and Tozitna terranes (Silberling and others, 1994; Till and others, 2006). Geophysical data suggest these terranes extend under the north and west sides of the basin (Saltus and others, 2007). Late Cretaceous (Maastrichtian) to Quaternary sedimentary strata are present in widely scattered exposures around the margins of the basin (Farmer and Ridgway, 2003; T.A. Ager, U.S. Geological Survey, written commun. to R.R. Reifenstuhl, 2003). These rocks are complexly folded and cut by high-angle faults. The least deformed section was encountered along the Hodzana River at The Mudbank, where Pliocene mudstones, sands, and gravels dip only a few degrees to the east. The location of the basin at the intersection of two major dextral strike-slip fault zones-the northeast-trending Victoria Creek fault zone and northwest-trending Tintina fault zone-undoubtedly exerted major control on basin development (fig. 1).

\footnotetext{
${ }_{1}^{1}$ Alaska Division of Geological \& Geophysical Surveys, 3354 College Road, Fairbanks, Alaska 99709-3707; david.lepain@alaska.gov

2 U.S. Geological Survey, 345 Middlefield Road, MS 969, Menlo Park, California 94025
} 
Exposures of Cenozoic sedimentary rocks in the uplands area bordering the basin, combined with gravity and two-dimensional seismic data, indicate that nonmarine strata are as thick as $8 \mathrm{~km}$ in the main depocenter near the Tintina fault, and that several subbasins expressed as gravity lows may be as thick as 4 to $7 \mathrm{~km}$ (Morin, 2002; Phillips and Saltus, 2005; Till and others, 2006). Two-dimensional seismic data allow recognition of at least three stratigraphic cycles, each interpreted to include different proportions of lake and fluvial sediments. No deep exploratory wells have been drilled in the basin, and the presence of petroleum source beds in the basin fill is unproven. Nevertheless, organic geochemical analyses of samples of potential petroleum source rocks from shallow coreholes and outcrops in the uplands near the Yukon Flats suggest that Paleogene and possibly Cretaceous nonmarine coal and mudstone likely generated thermogenic gas and possibly some oil, which may be trapped in sandstone and conglomerate reservoirs (Lillis and Stanley, 2005).

\section{DESCRIPTION OF SELECTED OUTCROPS VISITED DURING 2002 FIELD SEASON}

\section{THE MUDBANK}

\section{Description}

Approximately 6 to $7 \mathrm{~m}$ of poorly consolidated nonmarine gravel, sand, tuffaceous(?) silt, and silty clay are exposed on the north side of a prominent meander loop of the Hodzana River, referred to as The Mudbank, on the Beaver C-3 Quadrangle (figs. 1-3). The Mudbank exposure is approximately $80 \mathrm{~km}$ northeast of Exxon's Coal Creek corehole (location 86-3, fig. 1), which encountered Oligocene coal-bearing strata. Three Exxon coreholes (86-4, 87-7, and 87-8) are closer to The Mudbank than the Coal Creek corehole, but they encountered Quaternary sediments resting unconformably on Devonian sedimentary rocks, with no intervening Tertiary strata (fig. 1; LePain and Montayne, 2016).

The exposure extends for several hundred meters along the river bank (fig. 2a). Thin beds of lignite and carbonaceous mudstone are minor but prominent lithologies. The section is essentially undeformed and beds dip a few degrees, at most, toward the east. The age of the succession is poorly known. A sample of organic-rich mudstone from this outcrop yielded abundant, well-preserved fossil pollen of probable early Pliocene age (T.A. Ager, U.S. Geological Survey, written commun. to R.R. Reifenstuhl, DGGS, 2003).

Bleached light tan-brown to tan-gray siltstone and mudstone with a characteristic irregular blocky to chippy parting are the dominant lithologies at The Mudbank (fig. 3a). Laminae are not visible in mudstones. The bleached appearance suggests a volcanic ash component. Siltstones and mudstones include small (millimeter or less diameter) rootlets oriented at high angles to bedding and filled with carbonaceous material. Rootlets are concentrated in selected beds, but are also found scattered throughout the exposure. Low-relief scour surfaces up to $40 \mathrm{~cm}$ deep and $1 \mathrm{~m}$ wide are minor features in the siltstones. The scour surfaces are typically defined by thin accumulations of comminuted plant debris. Thin beds of plane-parallel laminated silty claystone are present. The irregular chippy to blocking parting of mudstones resembles poorly developed soil ped structures. Many parting surfaces are covered with a red-brown iron-oxide coating. No invertebrate macrofossils or trace fossils were observed.

Near the west end of The Mudbank exposure, a succession of poorly consolidated fine-grained sand and sandy pebble gravel is present immediately above river level (fig. 3b). Mudstone with compacted logs is visible at the bottom of the river adjacent to the sand and gravel succession. Viewing the area from the air at low altitude, we observed that the mudstones making up the eastern three-quarters of The Mudbank rest stratigraphically above the sand and gravel succession (fig. 3a), ruling out the possibility that the coarser lithologies are Pleistocene terrace sediments. The basal $1.8 \mathrm{~m}$ of section includes poorly sorted, silty, fine-grained sand that parts in irregular, 
fist-size pieces similar in shape and size to the mudstones encountered in the eastern part of the exposure. At least three gravel beds with sharp erosive basal contacts divide the basal sand. One pebble gravel bed, $0.2 \mathrm{~m}$ thick, displays well-developed clast imbrication, indicating paleoflow toward the east-northeast $\left(072^{\circ}\right)$. Sandy pebble gravel overlies the basal sand and is at least $3.2 \mathrm{~m}$ thick. The pebble gravel includes faintly visible, wavy, nonparallel beds 10 to $30 \mathrm{~cm}$ thick.

\section{Interpretation}

Facies preserved at The Mudbank, combined with the lack of macrofossils (shell and trace fossils), suggest deposition in a fluvial floodplain setting traversed by moderate(?)-sinuosity streams. The dominant lithology consists of bleached, light-colored siltstone and mudstone with an irregular blocky to chippy parting character suggestive of deposition in an alluvial overbank (floodplain) setting. The parting character and lack of preserved primary stratification suggests disruption after deposition by soil-forming processes. The light color is likely the result of some combination of a tuffaceous component, low organic carbon content, and a well-drained(?) floodplain setting. The presence of interstratified laminated claystone indicates occasional deposition from standing water following floods. Thin beds of coal and carbonaceous mudstone point to periodic colonization of the substrate by vegetation; some carbonaceous mudstones probably record deposition of transported plant material. Finegrained sand, thin interbeds of gravel, and sandy gravel record deposition in a fluvial channel.

\section{RAMPART}

\section{Description}

More than 1,700 m of Tertiary nonmarine strata are discontinuously exposed on the east bank of the Yukon River, approximately $2 \mathrm{~km}$ north of the village of Rampart, in the Tanana C-1 Quadrangle (figs. 1 and 4a). The exposure begins approximately $0.5 \mathrm{~km}$ north of Julia Creek (T8N, R13W, section 13) and continues north of Argo Gulch (section 12). The photomosaic in fig. 4a shows the discontinuous nature of the exposure. A late Paleocene(?) to early Eocene age was reported for Tertiary strata encountered in a shallow corehole (location 86-2) drilled near this exposure (unpublished industry data).

Two units are recognized in the Rampart section based on structural dip (bedding attitude), conglomerate clast compositions, and stratigraphic organization. Both units are characterized by resistant packages of pebble and cobble conglomerate with minor lenses of pebbly sandstone ranging from 2 to more than $10 \mathrm{~m}$ thick that are separated by recessive-weathering, mudstone-dominated intervals up to $15 \mathrm{~m}$ thick (upper unit).

\section{Lower Unit}

The lower unit is at least $700 \mathrm{~m}$ thick (southern half of exposure) and characterized by steeply dipping beds $\left(70^{\circ}-\right.$ $80^{\circ}$ toward the north). Resistant packages consist of interbedded light to medium brown and orange-brown, cobble and pebble conglomerate, pebbly coarse-grained sandstone, fine- to coarse-grained sandstone, and minor dark brown mudstone (figs. $4 \mathrm{~b}-\mathrm{c}$ ). Conglomerate beds include clast-supported fabrics and lack obvious clast imbrication. Matrix-supported conglomerates have been reported in this unit (unpublished industry data). Concave-upward scour surfaces with up to $3 \mathrm{~m}$ of relief are common and suggest the presence of multilateral channel-fills. Recessive weathering intervals include dark-brown mudstone, brown siltstone, and brown fine- to coarse-grained sandstone. Recessive weathering intervals in the lower unit vary in thickness but probably do not exceed $4 \mathrm{~m}$ and appear to be laterally discontinuous where scour associated with overlying conglomeratic units has cut through underlying fine-grained deposits and into a lower conglomeratic package. The clast population in the conglomerates and pebbly sandstones includes a significant percentage of mafic and ultramafic rocks, including clasts most likely derived from the Angayucham-Tozitna terrane (unpublished industry data). 


\section{Upper Unit}

The upper unit is up to $900 \mathrm{~m}$ thick (northern half of the exposure) and consists of moderately dipping $\left(10^{\circ}-20^{\circ}\right.$ toward the north), resistant bodies of conglomerate and sandstone separated by less distinct recessive-weathering sandstones, siltstones, mudstones, carbonaceous mudstones, and lignitic coals (fig. 4a). Coarse and fine packages are laterally continuous at outcrop scale, in contrast with the lower unit. Coarse- and fine-grained lithologies are light gray to light brown and, in general, distinctly lighter colored than those in the lower unit (fig. 4e). Resistant bodies are up to $4 \mathrm{~m}$ thick and include sandy pebble conglomerate with interbedded pebbly, medium- to coarsegrained sandstone. Conglomerate beds range from thin (less than a few centimeters) to thick (greater than $2 \mathrm{~m}$ ), are internally massive, have clast-supported fabrics, and are laterally continuous at outcrop scale. Sandstones are most commonly present as discontinuous lenses up to $1 \mathrm{~m}$ thick within conglomerates. Massive, plane-parallel bedded, and trough cross-stratified sandstones are common. Millimeter-thick discontinuous stringers of brown plant debris are common in conglomerates and sandstones. Fine-grained packages include siltstone, fine- to medium-grained sandstone, and high-ash(?) lignites up to $15 \mathrm{~cm}$ thick. Sandstones include a variety of tractiongenerated sedimentary structures including plane-parallel lamination, trough cross-bedding, and current ripple cross-lamination. Plant fragments are common on bedding planes and carbonized root structures are abundant in sandstones and siltstones. Lignitic coals are medium to dark brown and include readily recognizable plant material, including twigs and leaves. Rooted siltstones and sandstones are present directly below some coal seams.

\section{Interpretation}

The succession recognized at Rampart, combined with the abundance of terrestrial plant remains (including lignite) and the absence of any marine indicators, indicate deposition in an alluvial setting. Resistant bodies of darker-colored conglomerate and sandstone in the lower unit include abundant channel-scale, concave-up scours forming multistory and multilateral channel complexes. The laterally discontinuous nature, at outcrop scale, of resistant and recessive bodies in this part of the section suggests deposition in low-sinuosity braided streams. Intervening recessive-weathering successions record deposition in overbank settings. Numerous repetitions of resistant, amalgamated conglomerate and sandstone bodies separated by relatively thin mudstone-dominated successions suggest deposition in an unstable alluvial setting characterized by frequent channel shifting and occasional abrupt channel avulsions. Matrix-supported conglomerates reported by others in this part of the section suggest deposition in alluvial fan settings (unpublished industry data). Collectively, these observations suggest deposition near the basin margin in settings characterized by higher alluvial gradients. The source terrain likely included the Angayucham-Tozitna terrane.

A distinctive color change from medium to dark brown and orange-brown in the lower unit to light gray and light to medium brown in the upper unit indicates a change in provenance. A qualitative decrease in the percentage of mafic and ultramafic clasts was apparent between these two parts of the section (higher in the lower unit). The color change also appears to correspond with a change in fluvial style. The greater degree of lateral continuity recognized in both the resistant and recessive bodies in the upper unit records deposition in an alluvial setting characterized by greater stability (fewer channel-switching and abrupt avulsion events). Deposition from larger and/or higher-sinuosity streams with lower gradients is consistent with this observation, perhaps associated with an axial fluvial system.

The reason for the change in bedding attitude from the lower half of the outcrop to the upper half is unclear (fig. 4). When viewed from a boat, the outcrop's dip angle appears to gradually decrease from south to north. The steeper dips near the south end of the outcrop are probably the result of that part being closer to the Victoria Creek fault zone (fig. 1). It is possible the change in attitude records syndepositional motion on this structure. 


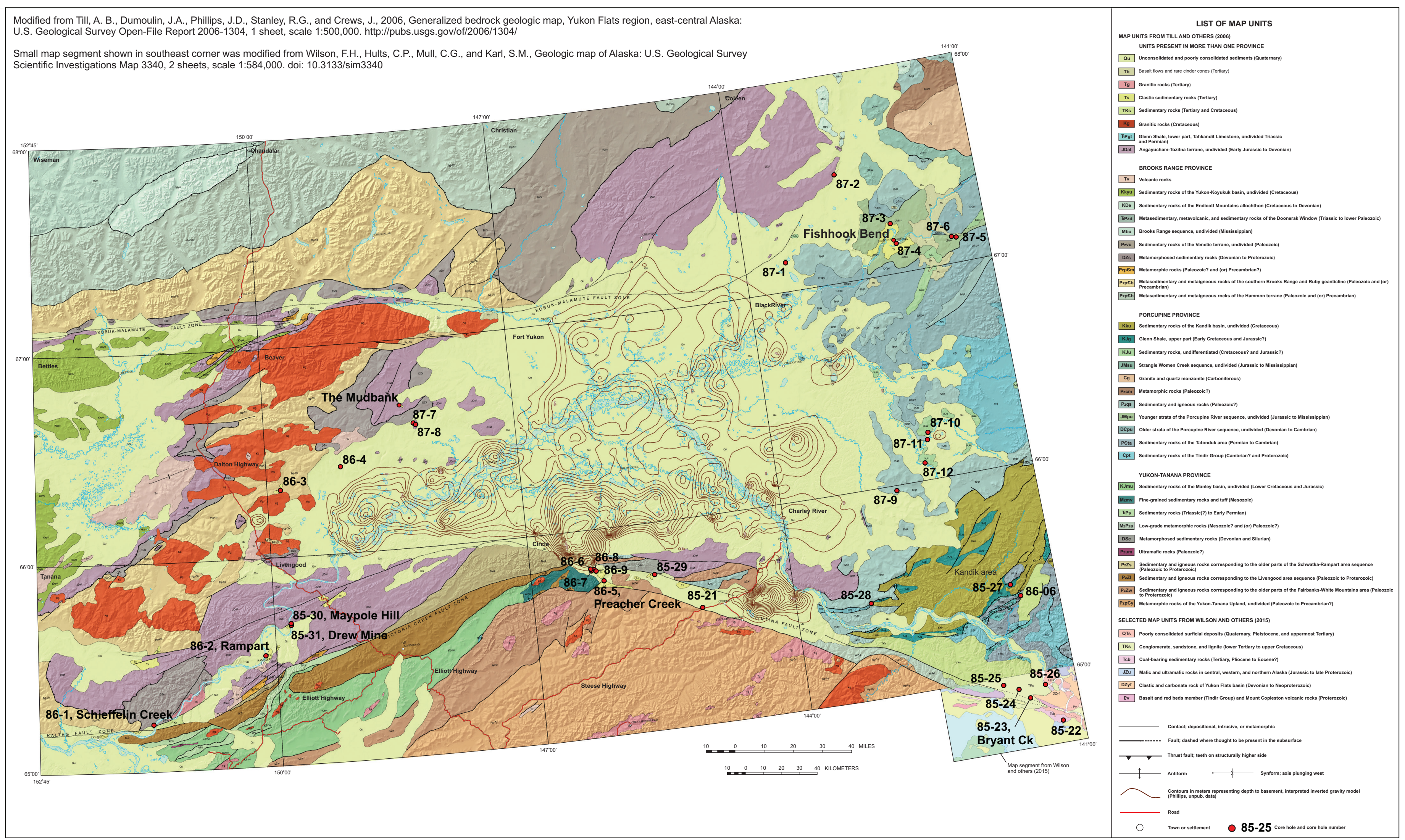

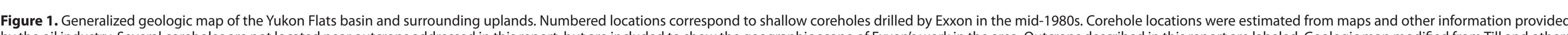

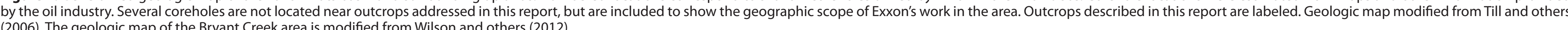




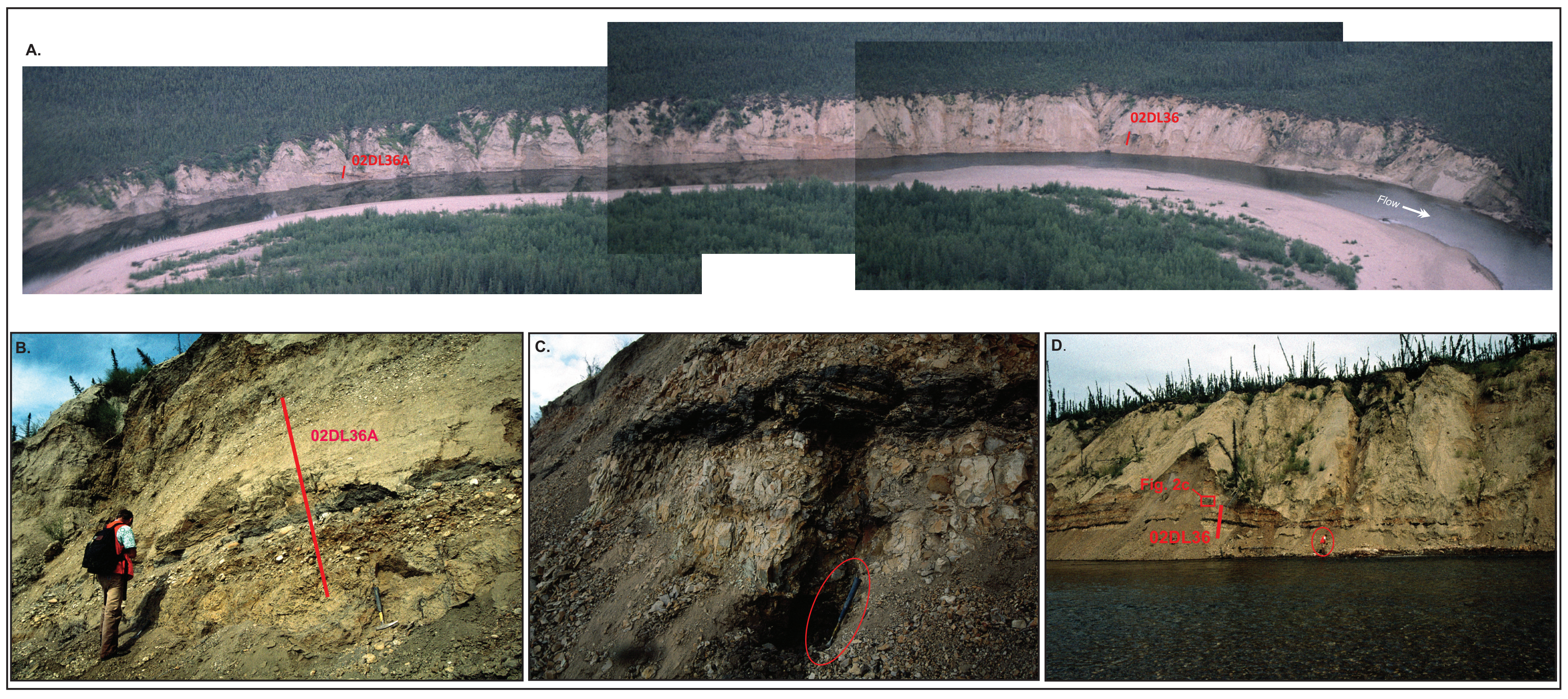

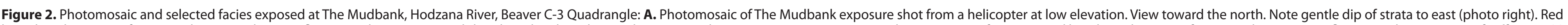

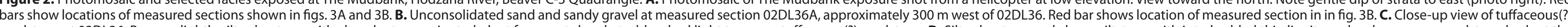

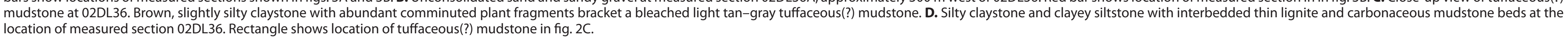


The Mudbank, Hodzana River

Beaver C-3 Quadrangle

$66.680^{\circ} \mathrm{N}$. Latitude $148.350^{\circ} \mathrm{W}$. Longitude

A. $02 \mathrm{DL} 36$

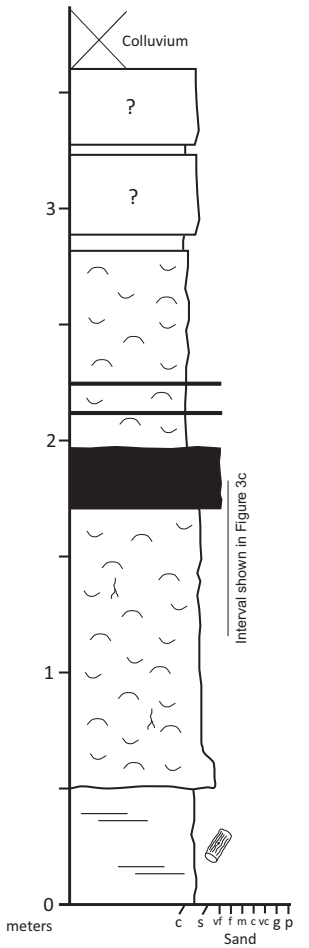

B. $02 \mathrm{DL} 36 \mathrm{~A}$

$\sim 250-300$ meters upstream

(west) of 02DL36

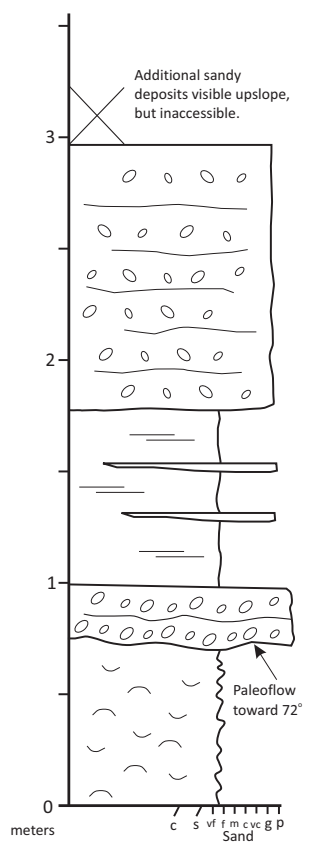

Description

Approximately 3-4 m of additional section discontinuously exposed upslope, but inaccessible.

Bleached tan-gray to tan-white, slightly silty claystone; blocky to chippy parting; coal seam up to $30 \mathrm{~cm}$ thick and at least two carbonaceous
mudstone beds (each less than $5 \mathrm{~cm}$ thick) are present above $3 \mathrm{~m}$; mudstone beds (each less than $5 \mathrm{~cm}$ thick) are present above $3 \mathrm{~m}$;
scattered small lignitic wood fragments to $0.5 \mathrm{~cm}$ long; scattered orangescattered small lignitic wood fragments to $0.5 \mathrm{~cm}$ long; scattered orange-
brown iron stains on fracture surfaces. Overall bleached appearance suggests significant volcanic ash content.

Dark brown lignite; plant stems clearly visible.

Brittle, blocky parting, bleached silty clay with abundant scattered twigs immediately below coal; low-relief ( $15-40 \mathrm{~cm}$ relief), concave-up scour
surfaces along strike, cut into silty clay and filled with organic-rich, silty clay.

Bleached tan-white to brown-gray clayey siltstone; scattered woody material at high angle to bedding - rootlets?

Blue-gray clayey, silty, sandstone.

Brown-gray, silty claystone; sub-millimeter-thick laminae; abundant plant material in form of woody stems and twigs.
Description Light gray to brown-gray sandy pebble gravel; unconsolidated; faintly visible
planar lamination defined by diffuse pebble trains in sandy gravel.

Light gray to brown-gray very fine-grained sandstone with centimeter-thick cover on gravel lenses; poorly consolidated.
cons

Tan-brown to orange-brown, polymictic, pebble conglomerate; poorly consolidated; well-developed clast imbrication; measurement of single pebble indicates paleoflow toward 72 . Tan-yellow, locally iron-stained, silty, fine-grained sandstone; highly broken
into fist-size and smaller irregular-shaped fragments.
Poorly drained floodplain subjected to occassional incursions of floodwaters
from nearby fluvial channel tracts. Fining-upward succession starting at 0.5 from nearby fluvial channel tracts. Fining-upward succession starting at 0.5 $\mathrm{m}$ suggests deposition al least a few hundred melers from active chann weathering character suggest pedoturbation and deposition in a poorly drained floodplain setting subjected to periodic drying. Bleached appearance of silty claystone and clayey siltstone suggests admixed volcanic ash and non-volcanic siliciclastic detritus.
Interpretation

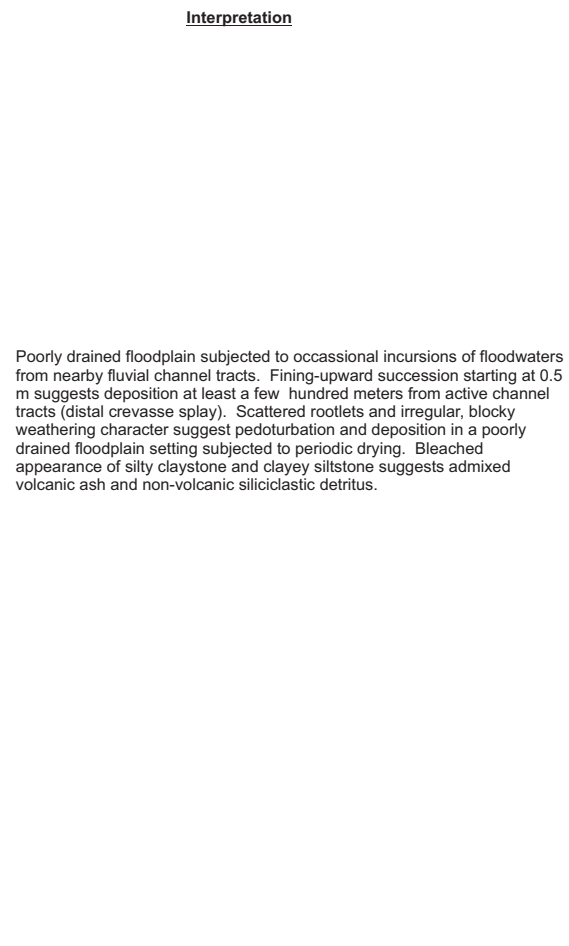

Interpretation

Fluvial channel-fill. Channel geometry (braided versus meandering) cannot be determined given the quality of the exposure.
Proximal levee? Blocky parting suggests periodic exposure and development of immature paleosol. Pebble gravel and fine-grained deposits. Channel margins were not observed, possibly due to the near coincidence of the exposure trend (east-west) relative to the paleo-transport direction (east-northeast).

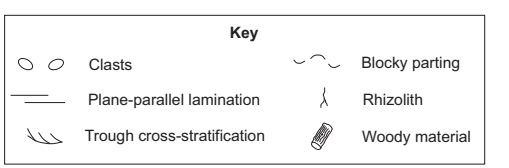

Figure 3. Reconnaissance measured stratigraphic sections from The Mudbank, Hodzana River. 


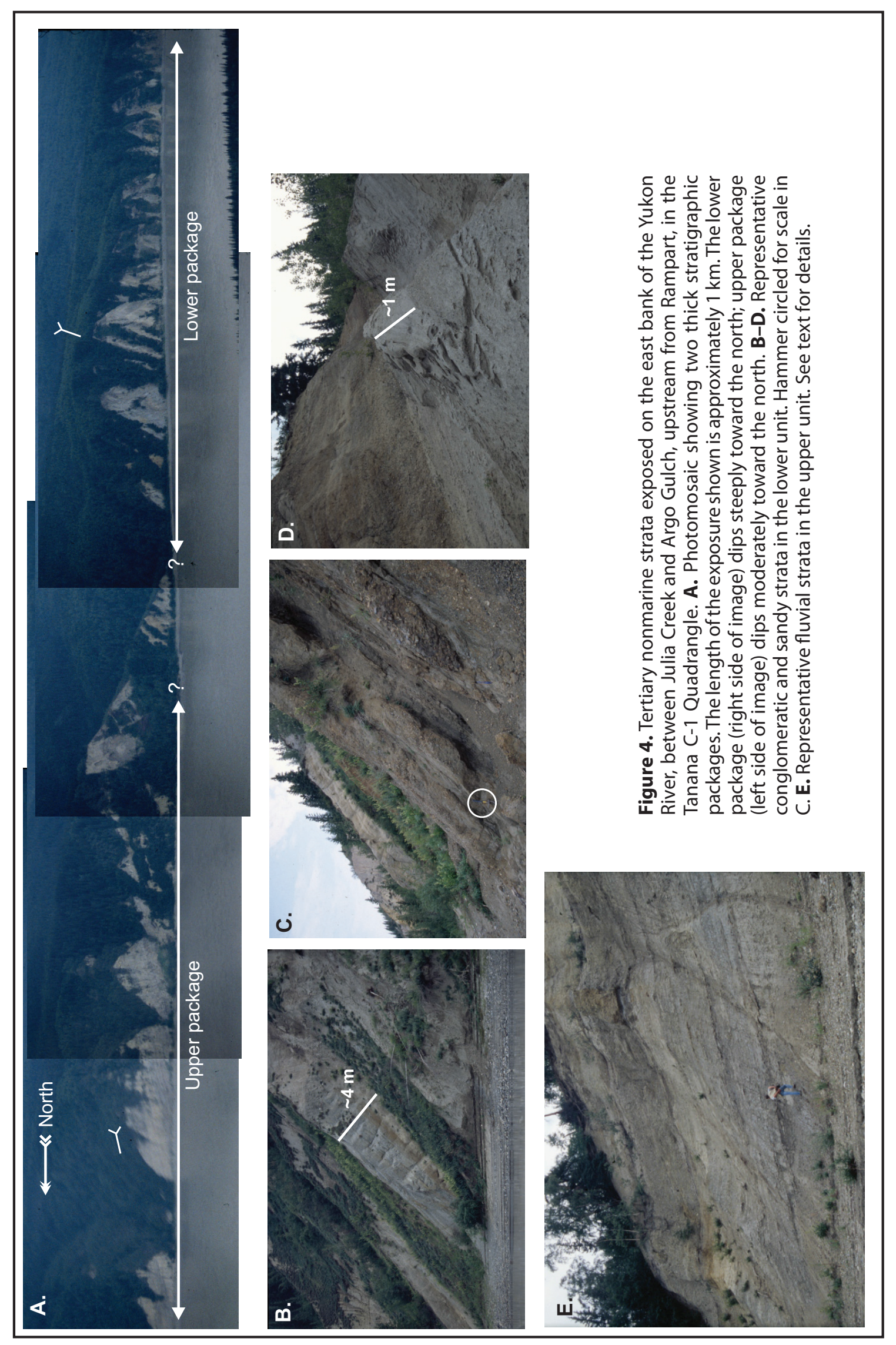




\section{BRYANT CREEK}

\section{Description}

Several hundred meters of steeply dipping Tertiary strata are exposed along the northwestern side of Bryant Creek, in the Eagle D-1 Quadrangle, southeast of the Yukon Flats basin (figs. 1, 5, and 6). The Bryant Creek section is in the Tintina trench, a structurally controlled depression associated with the Tintina fault zone that includes an unknown thickness of Tertiary sedimentary rocks. The presence of a sparse assemblage of fungal spores and pollen(?) recovered from mudstones penetrated in Exxon's Bryant Creek corehole (location 85-23), near the Bryant Creek exposure, suggests an early to middle Eocene age assignment (unpublished industry data; fig. 1).

Tertiary strata along Bryant Creek and the nearby Seventymile River resemble the basal third of the Rampart section in terms of gross stratigraphic organization-alternating resistant sandstone and conglomerate packages tens of meters thick separated by recessive-weathering, poorly exposed mudstone-sandstone packages also tens of meters thick (fig. 5a). Most resistant packages consist of pebble conglomerate and interbedded sandstone. Erosional scour surfaces with up to several meters of relief that are concave up toward the southwest suggest that the succession is vertical to slightly overturned (fig. 5a).

Where examined, resistant packages consist of massive, clast-supported pebble conglomerate and sandstone lenses. Clasts include tan quartzite, black to dark gray argillite, and light gray chert. Maximum clast diameter is $7 \mathrm{~cm}$.
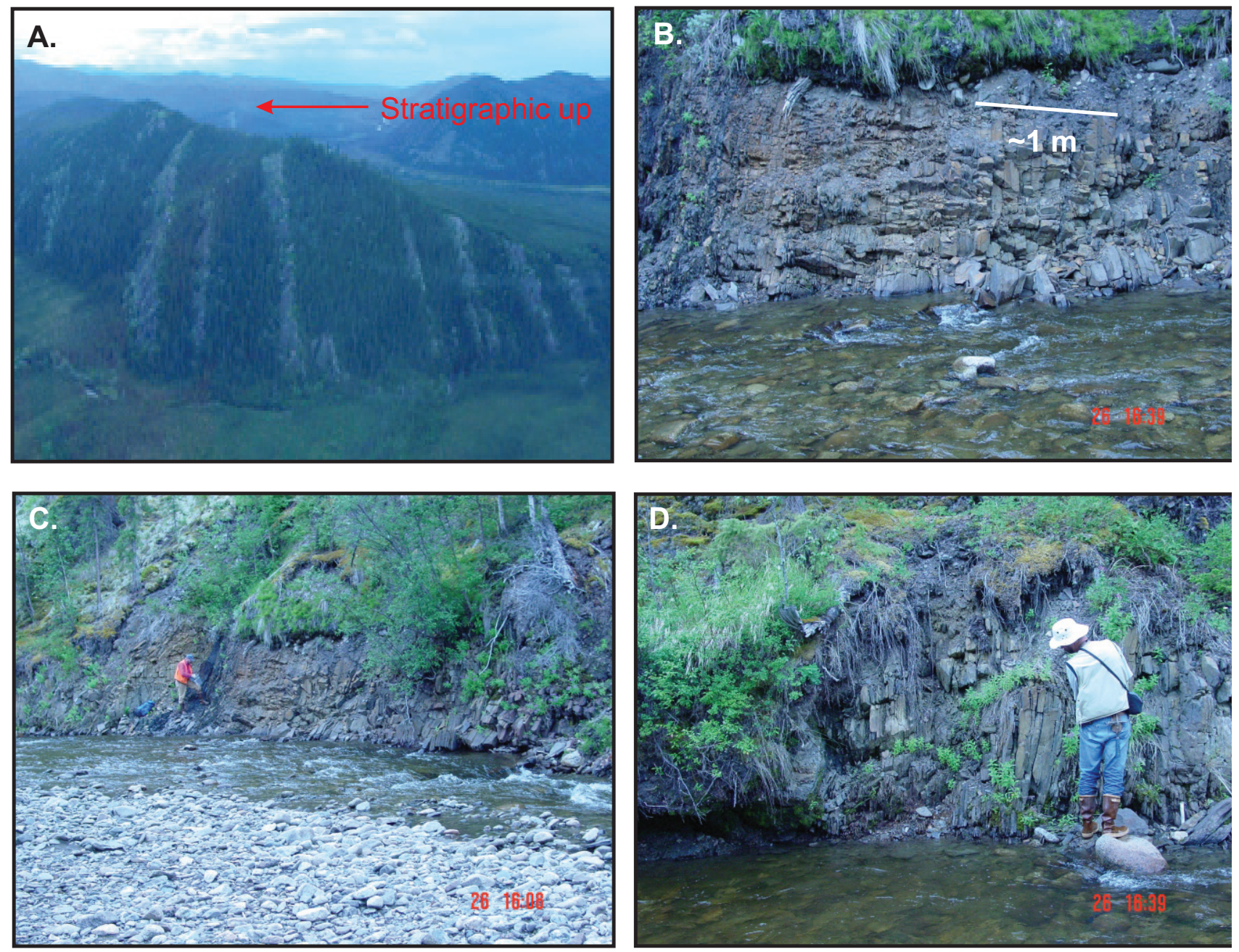

Figure 5. Tertiary nonmarine strata exposed along the northwest side of Bryant Creek, in the Eagle D-1 Quadrangle. Stratigraphic up is toward the left in all photographs. A. Aerial view toward the west, showing early to middle Eocene fluvial and lacustrine strata. B. Thin- to medium-bedded, fine-grained sandstone. Sandstone beds visible on the right side of the photograph gradationally overlie siltstone just beyond the right edge of the image. $\mathbf{C}$. and $\mathbf{D}$. Thin- to medium-bedded, fine- to medium-grained sandstone with minor interbedded siltstone and coal. Geologist in $\mathrm{C}$ is collecting a coal sample. 
Sandstones are medium- to thick-bedded and appear to lack abundant traction-generated sedimentary structures.

The sketch section shown in fig. 6 corresponds to the outcrop shown in figs. 5b-d, and portrays part of a recessiveweathering interval comprising a coarsening-upward succession of thinly laminated, silty shale, siltstone, and thin- to medium-bedded, fine- to medium-grained sandstone, with minor thin interbeds of carbonaceous mudstone, and clast-supported, thick-bedded pebble conglomerate. Plane-parallel laminae up to a few centimeters thick in siltstones are undisturbed by the activity of burrowing organisms or plant roots. Sandstone beds range from a few centimeters to approximately $20 \mathrm{~cm}$ thick. Plane-parallel bedded sandstones rest gradationally above plane-parallel laminated siltstones, and grade upsection to wavy, non-parallel bedded sandstones. A massive, clast-supported pebble conglomerate caps this particular exposure.

\section{Interpretation}

Alternating resistant and recessive-weathering packages of Tertiary strata exposed along Bryant Creek are interpreted as coarse-grained alluvial deposits (resistant weathering units) separated by finer-grained alluvial overbank and/or lacustrine strata (fig. 5a). The laminated silty clay shales and siltstones between 0 and $8 \mathrm{~m}$ in fig. 6 represent a deeper-water lacustrine facies deposited below lacustrine wave base and beyond the influence of lacustrine margin vegetation. Laminated siltstones grade upsection to lacustrine delta-front deposits between 8 and $28 \mathrm{~m}$. An alternative, but less compelling interpretation, is that this interval records channel levee deposits

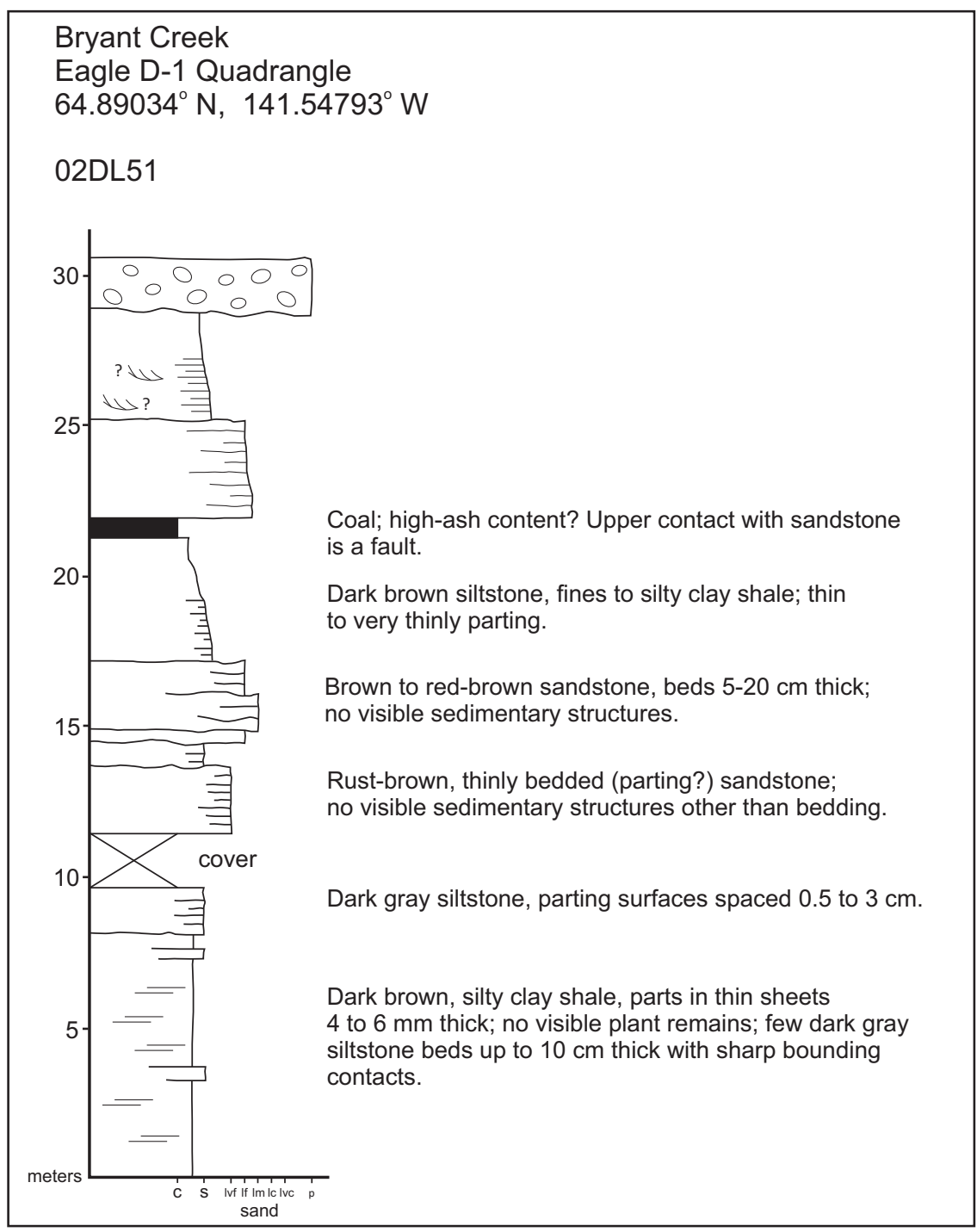

Figure 6. Reconnaissance measured section through lacustrine and fluvial strata exposed along Bryant Creek. 
developed along the margin of a perennial flood basin lake. This interpretation is not favored given the absence of features indicating subaerial exposure, which would be expected in the stratigraphically higher parts of levee deposits flanking a fluvial channel. The pebble conglomerate at $22 \mathrm{~m}$ in fig. 6 is interpreted as the basal deposit of a steep-gradient deltaic distributary channel-the basal channel scour probably cut away the stratigraphically highest part of the delta-front succession. Massive clast-supported pebble conglomerates and sandstones visible in fig. 5a suggest deposition from streamflow processes in low-sinuosity, gravelly, braided streams.

\section{OTHER UPLAND LOCATIONS}

Several other spots in the upland region bordering the basin were visited briefly during the 2002 field season (fig. 1). Locations include Drew Mine, Maypole Hill, and Schieffelin Creek, all along the northern bank of the Yukon River, west of the Dalton Highway, southwest of Yukon Flats. Several areas were visited in the vicinity of Preacher Creek, in the uplands between the White Mountains to the south and the flats to the north, in the Circle Quadrangle (fig. 1). Two locations were visited along the banks of the Porcupine River, including Fishhook Bend (fig. 1) and the Upper Ramparts (east of the eastern edge of the area shown in fig. 1), in the Coleen Quadrangle. The latter two areas have been described in detail by Fouch and others (1994) and are not described here. General descriptions and interpretations of the other locations are presented below.

\section{Drew Mine}

At Drew Mine, in the Livengood C-6 Quadrangle, limited exposures near river level include texturally and mineralogically immature sandstone and pebble conglomerate, carbonaceous mudstone and subbituminous(?) coal. Bedding dips steeply toward the south and is overturned locally. Stratigraphic up is toward the south, based on sole markings, trough cross-stratification, and ripple cross-lamination. The top of the exposure (south end) includes interbedded conglomerates and sandstone, and a few thin $(10-20 \mathrm{~cm})$ seams of coal. Conglomerates are green to medium gray, locally brown, polymictic, very poorly sorted, generally clast-supported, and include abundant mafic clasts. Sandstones are green-gray to green, poorly to moderately sorted, and include abundant mafic grains. Thick coal seams and carbonaceous mudstones are exposed near the base (north end) of the exposure.

The succession at Drew Mine suggests deposition in a relatively stable swamp/mire setting that was succeeded in time by coarse-grained alluvial deposition. The textural immaturity of sandstones and conglomerates suggests deposition in relative proximity to an upland source terrane, possibly associated with wet alluvial fans. The nearby Drew Mine corehole (fig. 1, location 85-31), penetrated an early to middle Eocene succession of alternating coarse-grained clastics (mainly sandstone bodies up to $15 \mathrm{~m}$ thick) and coal-bearing mudstones (greater than 16 m thick; unpublished industry data).

\section{Maypole Hill}

The exposure at Maypole Hill, also in the Livengood C-6 Quadrangle, is dominated by gray-green pebble conglomerates and fine- to coarse-grained sandstones. Both lithologies commonly include petrified wood fragments that have a bleached appearance. Coal was not found at this location and sandstones and conglomerates appear texturally mature (moderately sorted). Beds dip steeply toward the southwest and stratigraphic up is toward the southwest. The limited extent of the exposure and very limited time spent examining it preclude detailed description, but it appears similar in gross organization and lithological composition to the exposure at Drew Mine. These observations are consistent with streamflow processes in an active alluvial channel tract. A nearby corehole (fig. 1, location 85-30) penetrated an early to middle Eocene succession of coarse-grained clastic rocks (sandstones and conglomerates[?]) up to $12 \mathrm{~m}$ thick above a mudstone succession approximately $6 \mathrm{~m}$ thick (unpublished industry data). 


\section{Schieffelin Creek}

The exposure at Schieffelin Creek, on the north bank of the Yukon River upstream from its confluence with the Tanana River in the Tanana A-3 Quadrangle, is much better than exposures at Drew Mine and Maypole Hill (fig. 2). At least $30 \mathrm{~m}$ of section is exposed over a horizontal distance of at least $0.5 \mathrm{~km}$. The exposure is cut by at least two high-angle faults. Beds at the south end are flat lying or dip a few degrees southward and pass northward to low northerly dips, defining a broad, open anticline. Beds near the north end of the exposure dip 30-40 degrees northward. Clast-supported pebble conglomerates with lenses of pebbly sandstone dominate the exposure and continue laterally at least 10-20 m. Conglomerate beds are amalgamated, up to several meters thick, and included numerous low-relief scour surfaces. One conglomerate bed includes large-scale trough cross-beds greater than 1 $\mathrm{m}$ thick. Foreset stratification consists of alternating thick lamina of pebble and granule conglomerate and verycoarse- to coarse-grained sandstone. Sandstone lenses up to a few meters thick are common.

A slightly recessive weathering interval at least $5 \mathrm{~m}$ thick separates thick conglomerate-sandstone packages, and consists of a coarsening upward succession of red-brown-weathering chippy siltstone that grades upsection to interbedded siltstone and fine-grained sandstone. The coarse-grained lithologies resemble the Tertiary section exposed along the Alaska Range mountain front in southwestern Alaska, in the McGrath Quadrangle (Dickey, 1984; LePain and others, 2003).

The features described above are consistent with deposition by streamflow processes in large, low- to moderatesinuosity streams. Trough cross-bedded conglomerate indicates steady flows that were deep enough in some channel tracts for large, three-dimensional, equilibrium, gravelly bedforms to develop. Rooted horizons were not observed in the chippy mudstones that were examined. The lack of preserved roots and the overall appearance of the finer-grained lithologies suggests deposition in a floodplain setting subjected to subaerial exposure.

A nearby corehole (fig. 1, location 86-1) penetrated (in descending order) a late Eocene or(?) Oligocene succession of interbedded mudstone and sandstone in the upper $17 \mathrm{~m}$, a 4-m-thick sandstone succession, and a mudstone succession at least $4 \mathrm{~m}$ thick at the bottom of the hole (unpublished industry data).

\section{Preacher Creek}

Several industry coreholes were drilled in the vicinity of No Name and Preacher creeks, in the uplands on the south side of the Yukon Flats basin (fig. 1; Circle Quadrangle). An exposure of conglomerate near corehole 86-5, on the border between Circle C-5 and D-5 quadrangles, was examined briefly. Conglomerates are polymictic and clast supported and clast size ranges from granule to approximately $15 \mathrm{~cm}$. Clast segregation by size is apparent, with some beds composed only of clasts in the granule-to-pebble range, and other beds including clasts ranging from small pebbles to cobbles (up to $15 \mathrm{~cm}$ in diameter). Conglomerate beds range from $1.5 \mathrm{~m}$ to more than $3 \mathrm{~m}$ thick and were internally massive. Sandstones and finer-grained lithologies are rare at this location. Thick-bedded, massive conglomerates suggest deposition in low-sinuosity streams. The apparent absence of traction-generated structures suggests rapid deposition, possibly from hyperconcentrated flows (Nemec and Steel, 1984). Corehole 86-5 (fig. 1) penetrated a Paleocene succession including more than $38 \mathrm{~m}$ of interbedded mudstone, sandstone, and conglomerate (unpublished industry data). Mudstones are relatively minor compared to sandstones and conglomerates and the corehole appears to have penetrated the upper part(?) of the coarsening-upward succession.

\section{DISCUSSION}

With the exception of The Mudbank, all outcrops discussed in this report are in basin-margin positions, or in structural troughs that extend away from the basin. The facies documented at these locations indicate that coarser-grained detritus was available and alluvial gradients were able to transport the supplied load. The porosity and permeability characteristics of these facies at the time of deposition were likely good to excellent. Subsequent burial diagenesis and deformation associated with basin-margin fault systems degraded their reservoir characteristics. The porosity and permeability of samples collected from these outcrops ranges from negligible 
to good (Reifenstuhl, 2006). Sandy facies in the older rocks examined in outcrop, if present in the basin interior, are likely to be less deformed and at burial depths of several thousand feet. It is unknown how these conditions will affect reservoir quality. The Mudbank exposure includes fine-grained facies that are inferred to be common in the subsurface of the basin interior. Interbedded coarse-grained and fine-grained facies observed in outcrop, combined with facies documented at The Mudbank, suggest good potential for stratigraphic traps in the basin.

Sandstone composition varies along the basin margin, but quartz-rich litharenites appear to be abundant and commonly include some ductile grains (Reifenstuhl, 2006). Assuming the abundance of ductile grains in sandstones from the basin interior does not exceed the abundance documented at basin-margin locations, it is possible that sand bodies with fair to good reservoir quality are present in the subsurface. Fair to good reservoir quality combined with good potential for stratigraphic traps suggest that viable reservoir rock is present in the subsurface of the Yukon Flats basin. Test holes at Fort Yukon demonstrate the presence of coal seams in the shallow subsurface. If coals, carbonaceous mudstones, or other petroleum source rocks are present in the deeper stratigraphy of the basin, a functioning petroleum system may be present.

\section{ACKNOWLEDGMENTS}

We thank Jim Clough (DGGS) for arranging helicopter logistics for fieldwork in the Yukon Flats basin in 2002 and gratefully acknowledge Chris Potter (USGS) and Nina Harun (DGGS) for reviewing an earlier version of this manuscript.

\section{REFERENCES}

Dickey, D.B., 1984, Cenozoic non-marine sedimentary rocks of the Farewell fault zone, McGrath Quadrangle, Alaska: Sedimentary Geology, v. 38, no. 1-4, p. 443-463. http://doi.org/10.1016/0037-0738(84)90089-7

Dover, J.H., 1992, Geologic map and fold- and thrust-belt interpretation of the southeastern part of the Charley River Quadrangle, east-central Alaska: U.S. Geological Survey Miscellaneous Investigations Series Map 1942, 14 p., 2 sheets, scale 1:100,000.

Farmer, E.T., and Ridgway, K.D., 2003, Cretaceous-early Eocene two-stage basin development, Yukon Flats basin, north-central Alaska [abs]: Geological Society of America Abstracts with Programs, v. 35, no. 6, p. 560.

Fouch, T.D., Carter, D.L., Kunk, M.J., Smith, C.A.S., and White, J.M., 1994, Miocene and Pliocene lacustrine and fluvial sequences, upper Ramparts and Canyon Village, Porcupine River, east-central Alaska: Quaternary International, v. 22/23, p. 11-29. http://doi.org/10.1016/1040-6182(94)90004-3

LePain, D.L., and Montayne, Simone, 2016, Core fragment descriptions, Exxon core holes, uplands bordering Yukon Flats basin, east-central Alaska: Alaska Division of Geological \& Geophysical Surveys Raw Data File 2016-4, 2 p., 1 sheet. http://doi.org/10.14509/29576

LePain, D.L., Blodgett, R.B., and Clough, J.G., 2003, Sedimentology and hydrocarbon source rock potential of Miocene-Oligocene strata, McGrath Quadrangle-An outcrop analog for the Holitna basin: Alaska Division of Geological \& Geophysical Surveys Preliminary Interpretive Report 2002-5, 75 p. http://doi.org/10.14509/2870

Lillis, P.G., and Stanley, R.G., 2005, Evaluation of petroleum source rocks from Yukon Flats, east-central Alaska [abs.]: Geological Society of America Abstracts with Programs, v. 37, no. 4, p. 94.

Morin, R.L., 2002, Isostatic gravity map of Yukon Flats, east-central Alaska: U. S. Geological Survey Open-File Report 02-322, scale 1:500,000. http://pubs.usgs.gov/of/2002/0322/

Nemec, W., and Steel, R.J., 1984, Alluvial and coastal conglomerates-Their significant features and some comments on gravelly mass-flow deposits, in Koster, E.H., and Steel, R.J., eds., Sedimentology of gravels and conglomerates: Canadian Society of Petroleum Geologists Memoir 10, p. 1-31.

Phillips, J.D., and Saltus, R.W., 2005, Thickness of sedimentary rocks in the Yukon Flats basin, east-central Alaska, as estimated using constrained iterative gravity inversion [abs.]: Geological Society of America Abstracts with Programs, v. 37, no. 4, p. 94. 
Reifenstuhl, R.R., 2006, Yukon Flats basin, Alaska-Reservoir characterization study: Alaska Division of Geological \& Geophysical Surveys Report of Investigation 2006-1, 25 p. http://doi.org/10.14509/14910

Rowan, E.L., and Stanley, R.G., 2008, The Yukon Flats Cretaceous(?)-Tertiary extensional basin, east-central Alaska-Burial and thermal history modeling: U.S. Geological Survey Scientific Investigations Report SIR 2007-5281, 12 p. http://pubs.usgs.gov/sir/2007/5281/

Saltus, R.W., Phillips, J.D., Till, A.B., Stanley, R.G., and, Morin, R.L., 2007, Geophysical characterization of preCenozoic basement for hydrocarbon assessment, Yukon Flats, Alaska: U.S. Geological Survey Open-File Report 2007-1208, 1 plate. http://pubs.usgs.gov/of/2007/1208/

Silberling, N.J., Jones, D.L., Monger, J.W.H., Coney, P.J., Berg, H.C., and Plafker, George, 1994, Lithotectonic terrane map of Alaska and adjacent parts of Canada, in Plafker, George, and Berg, H.C., eds., The Geology of Alaska: Boulder, Colorado, Geological Society of America, The Geology of North America, v. G-1, plate 3, scale $1: 2,500,000$.

Stanley, R.G., Ahlbrandt, T.S., Charpentier, R.R., Cook, T.A., Crews, J.M., Klett, T.R., Lillis, P.G., Morin, R.L., Phillips, J.D., Pollastro, R.M., Rowan, E.L., Saltus, R.W., Schenk, C.J., Simpson, M.K., Till, A.B., and Troutman, S.M., 2004, Oil and gas assessment of Yukon Flats, east-central Alaska, 2004: U.S. Geological Survey Fact Sheet 2004-3121, 2 p. http://pubs.usgs.gov/fs/2004/3121/

Till, A.B., Roeske, S.M., Bradley, D.C., Friedman, Richard, and Layer, P.W., 2007, Early Tertiary transtension-related deformation and magmatism along the Tintina fault system, Alaska, in Till, A.B., Roeske, S.M., Sample, J.C., and Foster, D.A., eds., Exhumation associated with continental strike-slip fault systems. Geological Society of America Special Paper 434, p. 233-264.

Till, A.B., Dumoulin, J.A., Phillips, J.D., Stanley, R.G., and Crews, J.M., 2006, Generalized bedrock geologic map, Yukon Flats region, east-central Alaska: U.S. Geological Survey Open-File Report 2006-1304, 1 sheet, scale 1:500,000. http://pubs.usgs.gov/of/2006/1304/

Till, A.B., Stanley, R.G., O’Sullivan, P.B., Saltus, R.W., and Crews, J.M., 2005, Tectonic events leading to establishment of Yukon Flats basin, Alaska [abs.]: Geological Society of America Abstracts with Programs, v. 37, no. 4, p. 94.

Van Kooten, G.K., Watts, A.B., Coogan, James, Mount, V.S., Swenson, R.F., Daggett, P.H., Clough, J.G., Roberts, C.T., and Bergman, S.C., 1997, Geologic investigations of the Kandik area, Alaska, and adjacent Yukon Territory, Canada: Alaska Division of Geological \& Geophysical Surveys Report of Investigation 96-6A, 3 sheets, scale 1:200,000. http://doi.org/10.14509/2533 